\title{
Jacek Schmidt
}

Uniwersytet im. Adama Mickiewicza

Wydziat Antropologii i Kulturoznawstwa

Instytut Antropologii $i$ Etnologii

jschmidt@amu.edu.pl

(D) https://orcid.org/0000-0002-4074-5942

\section{Przestrzeń idealna - perspektywa władzy. Na przykładzie strzeżonych ośrodków dla cudzoziemców w Polsce}

\begin{abstract}
Zarys treści: Nadzorowana przez Straż Graniczną przestrzeń ośrodków detencyjnych dla cudzoziemców jest niedostępna dla obserwatorów z zewnątrz. $Z$ tych samych względów nie mamy wglądu $w$ praktyki związane $z$ administrowaniem tą przestrzenią, regulowaniem zachowań personelu i pensjonariuszy. W latach 2018-2019 przeprowadzono w ośrodkach pierwsze w Polsce eksploracyjne badania naukowe, które były ukierunkowane na rozpoznanie zasad i standardów organizacji przedmiotowej przestrzeni i funkcjonowania w niej wszystkich kategorii aktorów społecznych. W artykule zaprezentowano wycinek tych badań, jaki stanowią wyobrażenia funkcjonariuszy reprezentujących władzę na temat tego, jak powinien wyglądać i funkcjonować idealny ośrodek detencyjny dla cudzoziemców. Dane wynikowe pozyskano w trakcie serii wywiadów fokusowych, które przeprowadzono we wszystkich ośrodkach strzeżonych w Polsce.
\end{abstract}

Słowa kluczowe: strzeżone ośrodki dla cudzoziemców, detencja, przestrzeń/miejsce/ nie-miejsce

\section{Problem i metoda}

Centralnym przedmiotem rozważań w tym tekście będzie wizja idealnej przestrzeni detencyjnej, jaką artykułują funkcjonariusze Straży Granicznej zatrudnieni w ośrodkach strzeżonych (zamkniętych) dla cudzoziemców ${ }^{1}$. Temat ten stanowi wąski wycinek problematyki badawczej zespołowego projektu pracowników

1 W Polsce funkcjonuje sześć takich ośrodków w różnych lokalizacjach (Krosno Odrzańskie, Lesznowola, Kętrzyn, Białystok, Biała Podlaska, Przemyśl), które mogą pomieścić około 570 cudzoziemców. Sektor detencji cudzoziemców dysponuje około 700 etatami (większość przypada na zespoły/sekcje ochrony), w działalność instytucji zaangażowane są też podmioty zewnętrzne (służba zdrowia, firmy cateringowe i sprzątające, placówki edukacyjne oraz osoby duchowne). 
UAM i UJ pt. „Organizacja przestrzeni w polskich ośrodkach detencyjnych dla cudzoziemców", który zrealizowano w latach 2018-2019². Na obszernej liście zagadnień będących przedmiotem eksploracji autorów projektu znalazły się: uwarunkowania formalnoprawne organizacji przestrzeni fizycznej i społecznej instytucji detencyjnej, sposoby „odczytywania” tej przestrzeni przez wszystkich aktorów społecznych w niej funkcjonujących, ich codzienne praktyki/zachowania ujawniające się w relacjach wewnątrz- i międzygrupowych, wreszcie konsekwencje postaw personelu i pensjonariuszy dla relacji między nimi, a także kształtowania autowizerunków i obrazu instytucji (Niedźwiedzki, Schmidt 2020, s. 47-49).

Poglądy funkcjonariuszy SG na temat pożądanej postaci ich miejsca pracy były rekonstruowane przy wykorzystaniu serii wywiadów grupowych (Bohnsack 2004, s. 36-48, Barbour 2011). Idea wywiadów grupowych (fokusowych) polega na samobieżnej dyskusji osób w nich uczestniczących nad tematami/problemami zasugerowanymi w formie bodźców przez badacza - moderatora. Głównym celem badawczym jest ustalenie kolektywnych wzorów ujmowania rzeczywistości wyłaniających się $\mathrm{w}$ toku dyskusji. W każdym z sześciu strzeżonych ośrodków przeprowadzono po jednym wywiadzie, średni czas jego realizacji wyniósł 150 minut. W każdym badaniu uczestniczyło sześć osób reprezentujących wszystkie sekcje/zespoły pracownicze (wartowniczą, edukacyjno-wychowawczą/oświatową, konwojową, administracyjna). Udział w dyskusji był dobrowolny, w gronie uczestników znaleźli się funkcjonariusze wskazani przez pracowników sekcji/ zespołu, w którym pracują, osoby legitymujące się przynajmniej kilkuletnim stażem zawodowym w ośrodku. Zgodnie z zaleceniem badaczy nie było wśród nich przedstawicieli kierownictwa żadnego szczebla. Za zgodą osób biorących udział w badaniu było ono rejestrowane na dyktafonach, a pozyskane zapisy zutylizowano po wykonaniu transkrypcji, które zostały zaopatrzone w komentarze moderatora na podstawie prowadzonego dziennika obserwacji.

\section{Detencja cudzoziemców i wyróżniki jej przestrzeni}

Ponieważ wiedza o przedmiotowej formie detencji jest mało upowszechniona i reglamentowana przez władze, prezentacja danych wynikowych musi zostać poprzedzona podstawowymi informacjami na temat specyfiki ośrodków dla cudzoziemców i ich przestrzeni. Na mocy przepisów ustawowych (Ustawa z dnia 12 grudnia o cudzoziemcach 2020) ${ }^{3}$ i przypisanych do nich rozporządzeń detencji poddawani są cudzoziemcy w celu ustalenia bądź weryfikacji ich tożsamości,

Podane tu informacje przygotowano na podstawie dokumentów wewnętrznych ośrodków według stanu na koniec maja $2019 \mathrm{r}$.

2 Szczegółowy opis tego przedsięwzięcia - zob. Niedźwiedzki i Schmidt (2020). W trakcie tych pionierskich badań zgromadzono bogaty materiał źródłowy, na który złożyło się m.in.: 300 godzin nagrań wywiadów, kilkanaście tysięcy dokumentów pisanych oraz materiałów ikonograficznych oraz setki not obserwacyjnych.

3 Prawo polskie jest dostosowane do prawa unijnego (w tym Europejskiej Karty Praw Podstawowych oraz czterech dyrektyw regulujących kwestie detencji, a także prawa międzynarodowego, w szczególności różnych konwencji i deklaracji ONZ). 
zapobieżenia nadużyciu postępowania w sprawie udzielenia ochrony międzynarodowej, eliminacji zagrożenia dla bezpieczeństwa, zdrowia, życia lub własności innych osób, ochrony obronności lub bezpieczeństwa państwa albo ochrony bezpieczeństwa i porządku publicznego. Decyzję o umieszczeniu cudzoziemca w ośrodku detencyjnym podejmuje sąd właściwy dla miejsca pobytu imigranta na wniosek Straży Granicznej. Celem tej procedury jest przede wszystkim zabezpieczenie postępowania powrotowego (Sieniow 2016, s. 43-62).

Przestrzeń detencyjna jest odizolowana od świata zewnętrznego, dostęp do niej jest bardzo ograniczony, podlega ścisłej kontroli. Izolacja ta dotyczy także kontaktu przy użyciu telefonów komórkowych i Internetu ${ }^{4}$. Dla cudzoziemca umieszczonego w ośrodku jest to przestrzeń nieznana, wymagająca przyswojenia zasad jej organizacji oraz dostosowania się do reguł reglamentacji dostępu do poszczególnych miejsc, które opisane są w regulaminach i porządku dnia. Taka odgórnie zorganizowana przez władzę przestrzeń nie daje osobom w niej umieszczonym żadnych możliwości jej modyfikacji pod kątem podniesienia komfortu funkcjonowania w niej. Kolejnym opresyjnym wyróżnikiem przestrzeni i miejsc detencyjnych jest funkcjonowanie cudzoziemców pod pełnym i permanentnym nadzorem realizowanym za pomocą sieci monitoringu i obserwacji bezpośredniej wszystkich, wyłączywszy toalety, umywalnie i pomieszczenia sypialne, miejsc w ośrodku (skutkuje to minimalizacją prywatności życia, która obejmuje także zakres wykorzystania przedmiotów osobistego użytku). W przypadku detencji cudzoziemców mamy do czynienia ze szczególnym powiązaniem tej przestrzeni z czasem - osoba w niej umieszczona nie wie, jak długo będzie przymuszona do przebywania $\mathrm{w}$ niej ${ }^{5}$. Za dobre dopełnienie powyższej charakterystyki moga posłużyć sformułowania pojawiające się najczęściej w dziennych sprawozdaniach członków zespołu badawczego zapisywane w dziennikach terenowych: „druty”, „śluzy”, „inwigilacja”, „kontrola”, „więzienie”, „sterylne miejsce”, „miejsce totalnie uporządkowane”, ale też „rygor”, „upokorzenie”, „trauma”.

Strzeżone ośrodki dla cudzoziemców można zakwalifikować, posługując się terminologią Augé (2010), do kategorii nie-miejsc - przestrzeni przemijających (czasowych), tranzytowych, „nieantropologicznych” (bez tożsamości, ahistorycznych, nierelacyjnych). Plastyczny obraz takich miejsc można znaleźć w wypowiedzi literackiej Tokarczuk (2007). Z kolei Foucault (2007, s. 117-125) takie przestrzenie definiuje jako heterotopie dewiacji - lokalizowane w izolacji, nieakumulujące czasu, przejściowe, nietrwałe, efemeryczne, zawierające w sobie nieprzystawalne do siebie miejsca.

W 1787 r. wybitny reformator prawa i instytucji społecznych, filozof, prawnik i ekonomista Jeremy Bentham opublikował detaliczny projekt architektoniczny i organizacyjny panoptykonu (gr. pan - wszystko; optikos - widzieć) - idealnej przestrzeni detencyjnej (np. więzienia, aresztu czy zakładu psychiatrycznego), ale

4 W ośrodkach nie wolno posiadać własnego komputera, a udostępniany sprzęt uniemożliwia m.in. korzystanie z portali społecznościowych oraz przesyłanie obrazów.

5 Maksymalny czas pobytu w ośrodku strzeżonym nie może być dłuższy niż 12 miesięcy, jednak w praktyce wynosi średnio około trzech miesięcy. 
także innych miejsc, których aktorzy społeczni winni znajdować się pod nadzorem (np. fabryki, szkoły, szpitala) (Bentham 1835).

Dzięki wydanej w 1975 r. pracy Foucaulta Surveiller et punir. Naissance de la prison (1993) idea Benthama została przypomniana i upowszechniona w ramach koncepcji panoptyzmu. Dlatego przypomnijmy tylko najistotniejszą funkcję panoptykonu - umożliwia on nieprzerwane obserwowanie, a w niektórych wariantach też podsłuchiwanie osadzonego w odizolowanym pomieszczeniu, który ma świadomość takiego stanu, a jednocześnie nie widzi i nie słyszy osoby nadzorującej. Przeświadczenie o widzialności i słyszalności jest gwarancją samodyscyplinowania się, nawet gdy faktyczny nadzór jest nieciągły i wybiórczy. Z perspektywy władzy jest to sytuacja optymalna - czyni władzę zdepersonalizowaną, minimalizuje interakcje funkcjonariuszy z nadzorowanymi oraz między samymi pensjonariuszami, co ogranicza potencjalne konflikty i inne zagrożenia, obniża stresowość związaną z charakterem wykonywanej pracy, zmniejsza koszty działania instytucji, gdyż nie wymaga licznego personelu.

Wizja architektoniczna Benthama takiej przestrzeni dyscyplinującej jednostkę nie doczekała się pełnej realizacji, aczkolwiek w różnych częściach świata (Wielka Brytania, USA, Kuba, a także Polska - Areszt Śledczy w Toruniu) można zobaczyć obiekty detencyjne zbudowane $\mathrm{w}$ oparciu o inspiracje $\mathrm{z}$ projektu panoptykonu.

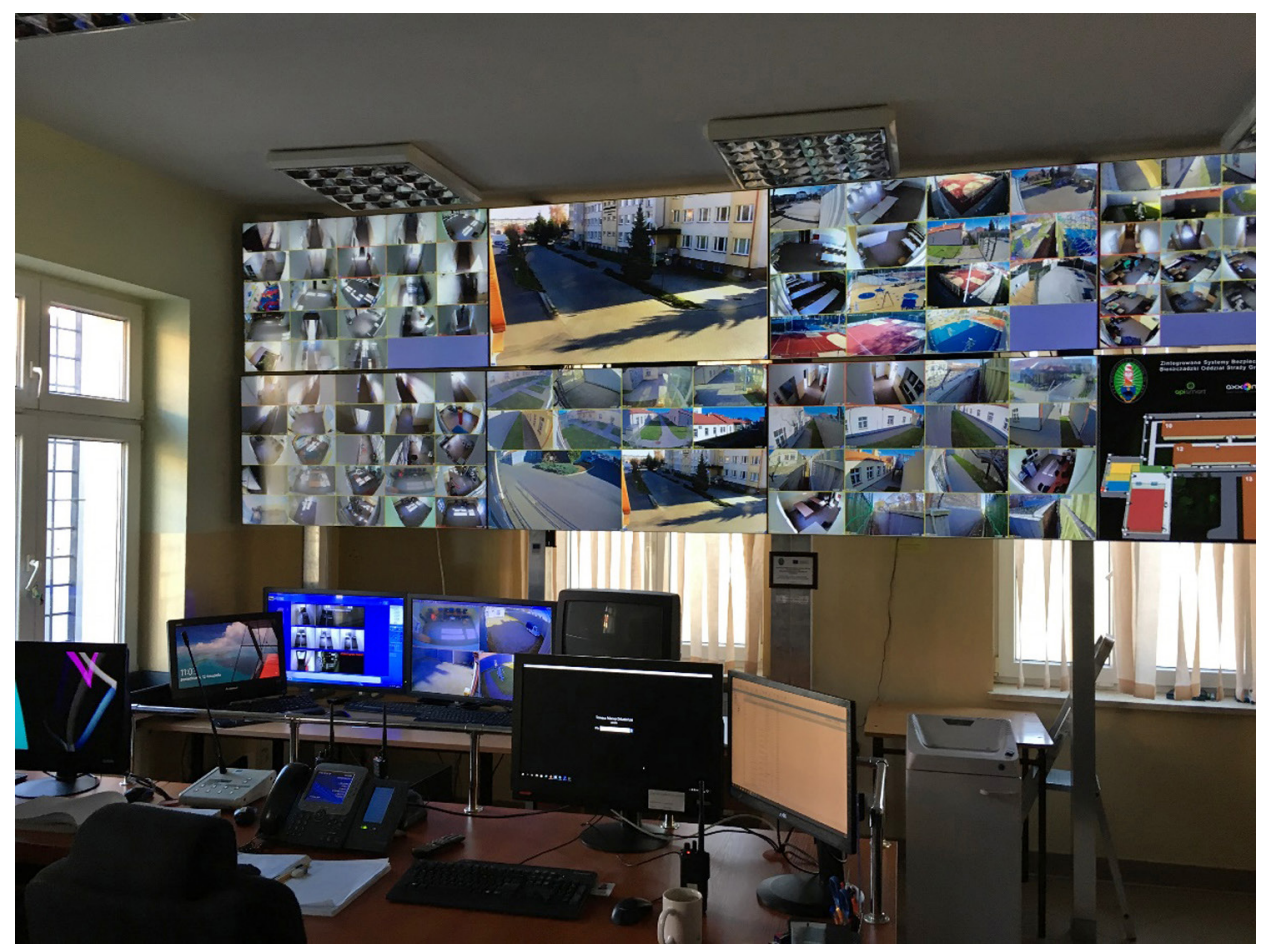

Fot. 1. Typowe pomieszczenie monitoringu (Białystok), kwiecień 2019 (fot. D. Niedźwiedzki) 
Natomiast dzięki współczesnym technologiom (w szczególności systemom monitoringu) efektywnie wdraża się zamysł organizacyjny Benthama. $\mathrm{Z}$ doświadczeń członków zespołu badawczego wynika, że w szeregu państw europejskich (np. Niemcy) ośrodki detencyjne dla cudzoziemców opierają się na permanentnej inwigilacji połączonej z daleko idącym odseparowaniem personelu od osób umieszczonych w detencji (Bosworth 2014).

\section{Wyniki badań fokusowych}

Badania fokusowe były anonsowane osobom w nich uczestniczącym pod hasłem „Idealny ośrodek strzeżony dla cudzoziemców - jaki powinien być”. Bodźce wywołujące dyskusje miały je ukierunkować na następujące kwestie: lokalizacje i szeroko rozumianą architekturę obiektów, ich wyposażenie, dobór i cechy personelu, zasady organizacyjne pracy ośrodka. Z trzech powodów analiza porównawcza wypowiedzi pojawiających się we wszystkich sześciu wywiadach okazała się niemożliwa. Po pierwsze, pomimo działania $\mathrm{w}$ ramach tych samych reguł prawnych każdy ośrodek detencyjny znacząco różni się od pozostałych. Stanowi zamknięty mikroświat. Uwaga ta dotyczy zarówno różnic na poziomie międzynarodowym, jak i w kontekście jednego państwa (Labanca, Ceccorulli 2014, s. 9-10). Po drugie, uczestnicy badania w swoich projekcjach odnosili się wyłącznie do specyficznego kontekstu ośrodka, w którym pracowali, albowiem nie mieli możliwości poznać innych instytucji tego typu. Po trzecie, tematyka dyskusji $\mathrm{w}$ wielu miejscach odchodziła od zamierzeń prowadzącego i obejmowała wątki niemieszczące się we wskazanym temacie badawczym.

\section{Czy ośrodki strzeżone dla cudzoziemców są w ogóle potrzebne?}

Interesujący jest fakt, że w toku dyskusji nie uzyskano zgodności poglądów w tej kwestii. Co prawda, większość uczestników badania odpowiadała twierdząco na tak zadane pytanie - podkreślała, że chodzi o istotne dla każdego z nich zachowanie miejsca pracy - jednak wskazywano przy tym na specyfikę służby, w której w każdej chwili można być przekierowanym do pracy poza ośrodkiem detencyjnym. Innymi przesłankami na rzecz utrzymywania ośrodków były: bezpieczeństwo i obronność państwa, niezgoda na naruszanie przez cudzoziemców prawa polskiego i unijnego, które jest działaniem świadomym, często uporczywym, związanym $z$ realizowaniem partykularnych interesów (np. chęcią podreperowania stanu zdrowia). Reprezentatywne wypowiedzi:

(...) jeśliby nas w moment rozdysponowali. Są takie braki, że (...) Czy na Okęciu, czy na oddziale, czy Modlin, to zaraz by nas rozdysponowali. Jak nie to, to byśmy robili po prostu coś innego gdzie indziej, ale w tej samej 
firmie (...) potrzebne te ośrodki, ponieważ bardzo dużo osób przebywa u nas w ośrodku, które nie mają tak naprawdę ustalonej tożsamości i dopóki nie ustalimy, kto to w ogóle jest, skąd on się znalazł i jaką drogę przebył, to raczej nie powinien sobie - moim zdaniem - wolno po ulicy biegać. Tak, tak, ale takie osoby też nie mogą, że tak powiem, samopas być puszczone po Polsce i ktoś tam będzie ich szukał, łapał, żeby podpisał dokumenty, bo wyjaśniła się sytuacja formalnoprawna i w rezultacie, żeby dostał taką decyzję, taką jak tutaj. Także w tym miejscu muszą być jakby te osoby i czekać na decyzję.

Z kolei osoby wyrażające sceptycyzm odnośnie do prowadzenia ośrodków detencyjnych wskazywały na konieczność wypracowania nowych, bardziej elastycznych przepisów i procedur, które umożliwią inną formę kontroli nad cudzoziemcem, będą uwzględniały różnorodność przypadków w zakresie formy naruszania przepisów przez cudzoziemców, ich sytuacji rodzinnej i stanu zdrowia, konsekwencji odesłania ich do kraju pochodzenia. Niezależnie od tego podkreślano, że czas przetrzymywania cudzoziemca w ośrodku detencyjnym jest zbyt długi, wynika ze zbyt wolnej pracy sądów i złożonych, wieloetapowych procedur odwoławczych. Reprezentatywne wypowiedzi:

Powinna być (...) taka dobrowolność, jeżeli chodzi o osobę. Jeżeli mają możliwość i wskazują jakieś tam adresy i tam faktycznie czekają, przebywają, jak jest taka możliwość i na tyle przepisy udałoby się zmienić, to moim zdaniem tak powinno to wyglądać. A jeżeli osoby nie (...) No są też osoby, którym nie przeszkadza np. pobyt w ośrodku (...) Są potrzebne, ale ja uważam, że tutaj zdecydowanie za długo są rodziny przetrzymywane. Powinien ten czas, tego całego etapu, być skrócony do trzech miesięcy. Nie dłużej. Przede wszystkim dla takich rodzin z małymi dziećmi, jak są takie dzieciaki, nie mają tutaj dzieciństwa. Jest jakby ograniczone. Tylko mur dookoła, funkcjonariusze. Jakiś taki strach, respekt też czują. Ośrodki są potrzebne, tylko powinna być procedura skrócona na pewno. Bo trwa zbyt długo i tyle. To jest jakby taka wada systemu może. Wszystko to trwa tyle czasu, że za długo. Dzisiaj, nawet patrząc na inne kraje, tak, to tam taka procedura przechodzi bardzo szybko. Ile osób oni przerobią w ciągu roku, a ile nasze ośrodki czy tam te urzędy ds. cudzoziemców są w stanie przerobić? Tu tylko wystarczy popatrzeć na statystyki chyba i będzie wiadomo (...) Nawet cudzoziemcy się śmieją, że Polska to jest „Waiting Land”. Na wszystko się czeka. Proszę czekać. Czekamy. Straż Graniczna - proszę czekać, ośrodek - proszę czekać (...) 


\section{Dobór personelu, podnoszenie kwalifikacji, zakres obowiązków, dobrostan pracownika}

Do pracy w ośrodku powinni trafiać ludzie, którzy chcą w nich pracować, a nie osoby „z przydziału”. Istnieją rozbudowane procedury kwalifikacyjne, ale na ich podstawie trudno wykryć rasistowskie czy ksenofobiczne poglądy kandydata, które często ujawniają się dopiero w trakcie pracy z cudzoziemcami. Reprezentatywne wypowiedzi:

Jakieś weryfikacje wstępne, nie, tak, jak przyjmują nas ogólnie do SG, przechodzimy wszelakiego rodzaju testy psychologiczne, sprawnościowe itd., to też tutaj dobrze by było, gdyby ktoś mądry stworzył jakiś taki system, aby wychwycić zapędy rasistowskie i uprzedzeniowe (...) Nie wiem, może to powinno wyglądać $\mathrm{w}$ taki sposób, że nie wiem, jakiś okres próbny czy coś, zobaczyć, jak ta osoba daje sobie radę ze stresem we współpracy z tymi cudzoziemcami i tak dalej (...) Bo jak powinny być dobierane osoby? Na pewno pod kątem językowym, bo nie wyobrażam sobie, zwłaszcza jak my mamy do czynienia z cudzoziemcami z tej grupy czeczeńskiej czy coś takiego (...) Przyjdzie człowiek z angielskim, ale tak naprawdę, co mu ten angielski tutaj da? Doświadczenie też jest ważne (...) trzeba by było najpierw spojrzeć na to, jak i gdzie my mamy pracować, w jakiej sekcji, tak. To przede wszystkim. Bo jak ja zajmuję się pracą z dziećmi, to jest inaczej, jak ktoś administracyjną, to wiadomo, wtedy dokumenty jakieś i jest zupełnie inaczej.

Niezwykle pożądane są kompetencje językowe dostosowane do potrzeb pracy z cudzoziemcami pochodzącymi z różnych obszarów kulturowych. W idealnym ośrodku powinny być realizowane różne formy dokształcania z zakresu prawa, wiedzy o życiu społecznym i kulturze cudzoziemców i ich języków. Reprezentatywne wypowiedzi:

Generalnie ośrodek sam w sobie jest na tyle specyficzną komórką, że my tutaj jesteśmy poniekąd samoukami, bo wszystko, wszystkie akty prawne, wszystkie materiały, na których my pracujemy, to jest na zasadzie takiego samokształcenia się, robienia sobie we własnych sekcjach burzy mózgów, tak, i - słuchajcie, weszła nowa ustawa. Ci, którzy nas szkolą często w ośrodkach szkoleniowych, oni nie mają praktyki kompletnie w ośrodku (...) I w sumie nie wiadomo, kto kogo uczy. Słownictwo takie ośrodkowe itd. I takich kursów nie ma. A jak się pojawiają, to nie wnoszą nic, bo osoby, które przyjeżdżają szkolić, bo były takie dwa lata temu, trzy lata temu, to pani uczyła mnie po rosyjsku mówić, która jest godzina. Szkolenia kulturowe? Odbyłem ich pięć. I z żadnego nic nie wyniosłem. Z żadnego. W celach turystycznych no to można się szkolić na takim szkoleniu, ale nie do tej roboty. Potrzebna jest elastyczność form dokształcania, taka nieszablonowość. 
Jednocześnie przełożeni winni wspierać wszelkie indywidualne inicjatywy edukacyjne funkcjonariuszy. Reprezentatywne wypowiedzi:

Jeszcze powinni być ci pracownicy, funkcjonariusze, wspierani, jeżeli chcą się dodatkowo edukować, bo to tak kuleje u nas. Niesamowicie. Ja jakiś czas temu, parę lat temu, napisałam prośbę o urlop $z$ tytułu podjętych przeze mnie studiów, kolejnych, bo to już mój czwarty fakultet, i to z psychologii klinicznej. I dostałam odmowę. Bo nie. A ze względu na politykę mojego oddziału Straży Granicznej nie dostanę dwudziestu dni urlopu. Na studia!

$\mathrm{Z}$ racji pracy $\mathrm{w}$ warunkach bardzo stresowych każdy funkcjonariusz winien mieć zapewniony dostęp do konsultacji psychologicznej, niekiedy też psychiatrycznej, która winna być przeprowadzona poza nadzorem przełożonych. Reprezentatywne wypowiedzi:

Ja myślę, że ogólnie dla wszystkich, którzy mają kontakt z cudzoziemcami, w razie jak jest potrzeba, albo takie jakieś spotkanie może z psychologiem, jakby ktoś potrzebował, albo taka superwizja na przykład. Czy jakiś taki wyjazd antystresowy. Może tak, może w tej wersji.

Wśród najczęściej wymienianych cech charakterologicznych funkcjonariusza znalazły się: tolerancyjność połączona z cierpliwością, ugodowość, niekonfliktowość, ale także stanowczość.

\section{Co jest potrzebne funkcjonariuszom?}

Bardzo istotnym punktem dyskusji była kwestia poprawy warunków pracy funkcjonariuszy. W ośrodkach brakuje przestrzeni socjalnej z odpowiednim wyposażeniem (fotele, kanapy, ekspresy do kawy), w której można by zrelaksować się, porozmawiać ze wspólpracownikami. Równie uciążliwy jest brak sal przeznaczonych do podnoszenia sprawności fizycznej funkcjonariuszy. Poważnymi utrudnieniami są także: zbyt mała liczba toalet i ich lokalizacja, niedobór środków higieny, konieczność częstego poddawania się kontroli dostępu podczas przemieszczania się po ośrodku czy niemożność wyprania odzieży w miejscu pracy. W okresie letnim we wszystkich ośrodkach panują trudne warunki termiczne, które sprawiają, że wszystkie pomieszczenia powinny zostać wyposażone w klimatyzatory i rolety. Na warunki pracy składają się też: złe oświetlenie, brak dostatecznej liczby drukarek, mała dostępność tłumaczy, brak odizolowanych miejsc do przyjmowania interesantów, brak weneckich luster, które izolowałyby niektóre pomieszczenia od cudzoziemców. Reprezentatywne wypowiedzi:

My się czujemy gorzej od cudzoziemców traktowani, naprawdę. Mi się wydaje, że oni mają więcej wygód i (...) Jak oni coś napiszą czy jak oni złożą na kogoś skargę, to od razu dzieje się na już. A my możemy tylko wnioskować, 
prosić. I zazwyczaj z tych próśb nic nie wynika. Faktycznie, brakuje takiego miejsca, gdzie można by było odreagować. Żeby sobie gdzieś tam się zresetować, zrelaksować się. To na pewno. $\mathrm{Z}$ mojej perspektywy też wiele do życzenia pozostawiają te miejsca, w których spożywa się posiłki, przygotowuje posiłki. Jak również to, żebyśmy byli oddzieleni od tych cudzoziemców, a nie jakby z nimi. W tym sensie, że mamy swoją dyżurkę, ale niekoniecznie umiejscowioną $w$ tym przedziale, gdzie przebywają cudzoziemcy. Chciałabym mieć takie pomieszczenie, że ja zapraszając kogoś z zewnątrz, np. tłumacza, który pomaga mi przy przyjęciu wniosku o udzielenie ochrony cudzoziemca, mam ten komfort, że on też jest z jakimś szacunkiem traktowany. No, nie każę mu siedzieć na skraju biurka, tak, pod kamera, w pomieszczeniu, gdzie co chwilę ktoś stuka, puka, tu telefon dzwoni, coś tam. Chodzi o zaplecze socjalne dla cudzoziemców i zaplecze socjalne dla funkcjonariuszy, to jest żenada dla mnie. Bo funkcjonariusz, który przebywa dwanaście godzin wśród cudzoziemców ma jeden mundur, w którym przychodzi z domu, pełni służbę, nie ma możliwości wyprania sobie tego munduru tutaj w pracy.

\section{Co jest potrzebne cudzoziemcom?}

Lista postulatów dotyczących potencjalnej optymalizacji warunków funkcjonowania w ośrodku jest bardzo obszerna. Otwiera ją kwestia pomieszczeń mieszkalnych. Należałoby, wyjąwszy pokoje rodzinne, zmniejszyć do dwóch, maksimum trzech liczbę lokatorów w jednym pomieszczeniu. Reprezentatywne wypowiedzi:

Żeby były mniejsze te pokoje. Znaczy mniejsze (...) Mniej zakwaterowane, żeby tam było czterech cudzoziemców, a nie ośmiu. Lepiej, żeby nie było tych łóżek piętrowych, bo to jednak są w różnym wieku ludzie - to mi się tak wydaje. A już nie mówię o zewnętrznej tej formule, że ona jest po prostu strasznie przygnębiająca i wystarczy po prostu tydzień, żeby depresję załapać.

W skład umeblowania winny wchodzić krzesła, stoliki i większe szafy, przy każdym pokoju powinna znaleźć się łazienka lub przynajmniej umywalka. Należałoby zlikwidować łóżka piętrowe i zakupić lepsze materace. W każdym pokoju powinien znajdować się telewizor i komputer, klimatyzacja lub przynajmniej rolety albo przyciemnione szyby - bez krat! Reprezentatywne wypowiedzi:

Dzięki takiemu wyposażeniu można byłoby zlikwidować sale komputerowe i świetlice telewizyjne - miejsca, w których najczęściej dochodzi do konfliktów między cudzoziemcami, wykorzystać te miejsca w innych celach. W każdym pomieszczeniu mieszkalnym Internet i telewizor. To koniecznie. Bo to by ułatwiło każdemu życie. Zarówno cudzoziemcom, jak i osobom pozostałym. Bo po prostu byłoby mniej kłótni. 


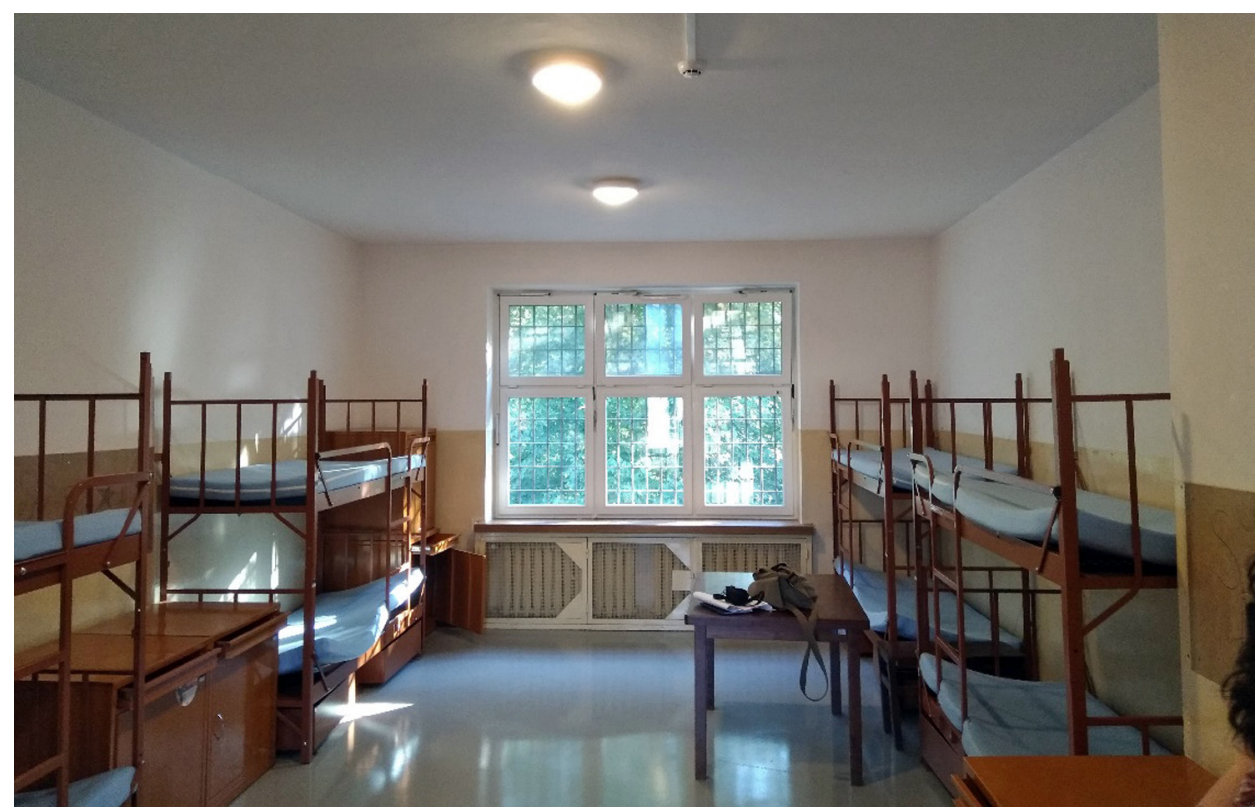

Fot. 2. Różnorodność standardów mieszkaniowych (Krosno Odrzańskie), październik 2018 (fot. J. Schmidt)

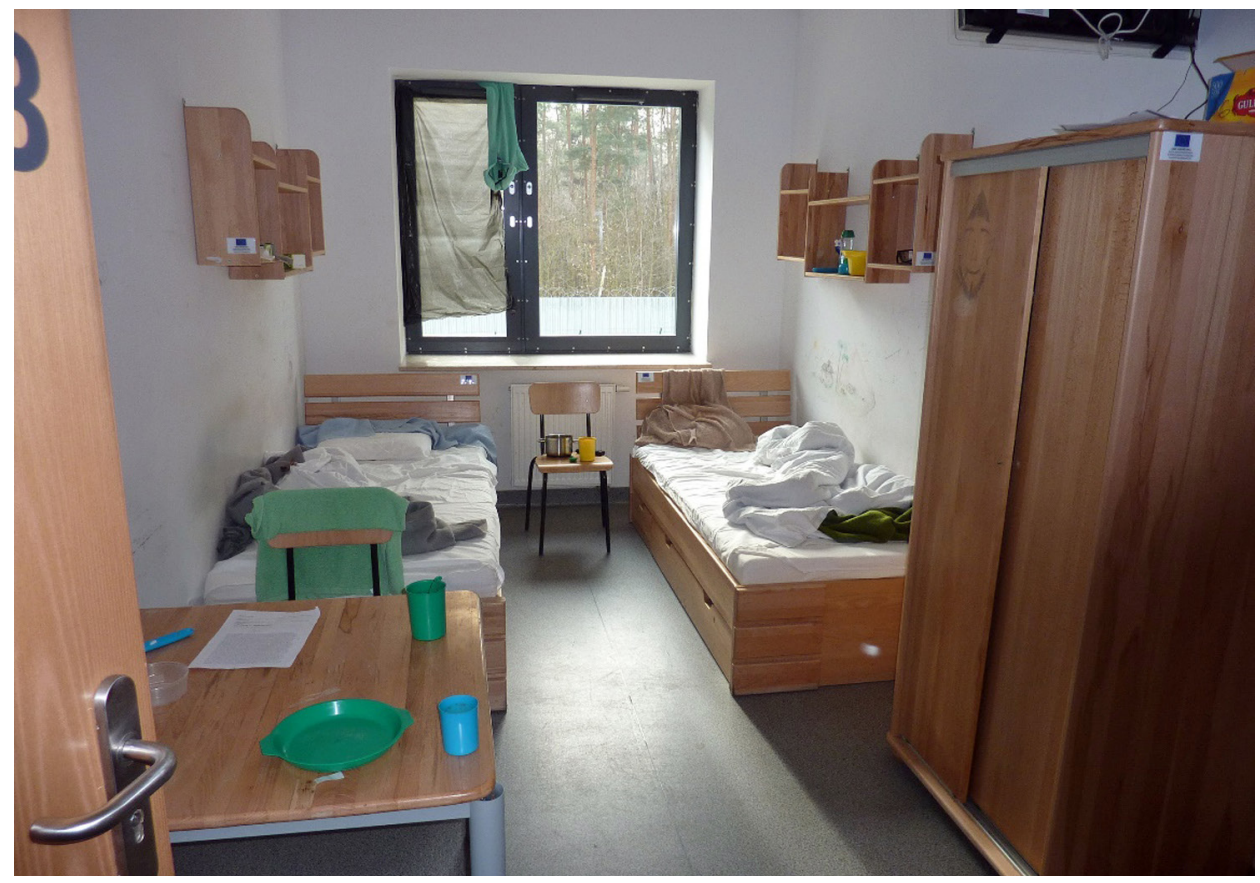

Fot. 3. Różnorodność standardów mieszkaniowych (Lesznowola), luty 2019 (fot. J. Schmidt) 
Modyfikacji (zakup większych stołów i krzeseł) wymagają też kuchnie, w których znacząca część cudzoziemców ze Wschodu spędza dużo czasu. Sporo do życzenia pozostawia estetyka wszystkich pomieszczeń - należałoby wprowadzić jakąś „wyciszającą” kolorystykę, znaleźć miejsca na eksponowanie prac plastycznych i in. cudzoziemców. Reprezentatywne wypowiedzi:

Dużo kolorów za kratą - chodzi mi o to, że nie każdy zna język, natomiast, jeżeli posługujemy się kolorami i jedna jest zielona, a druga czerwona, a pokój do spożywania posiłków jest pomalowany, nie wiem, na jakiś beżowy kolor, to jest łatwiej nawet komunikować się z cudzoziemcami, tak, bo mogę mu pokazać kolor wtedy i coś takiego, tak? Ja bym chciała jednak, żeby w takim ośrodku było kolorowo i te pomieszczenia miały jakieś swoje (...), pokój, który ma służyć do tego, żeby z cudzoziemcem porozmawiać na temat jego stanu psychofizycznego, to też powinien być w jakichś takich barwach spokojnych. Natomiast siłownia, gdzie ja mam się pakować, to niech ona będzie taka czerwona, niech oni mają motywację (...)

Istotne znaczenie, także dla wizerunku całej instytucji, mają pokoje widzeń, które nie powinny przypominać analogicznych pomieszczeń znanych z więzień. Reprezentatywne wypowiedzi:

Ja chciałabym się tutaj pochylić nad pokojem widzeń, bo on nie jest odpowiednim miejscem, np. do spotkań z rodziną, ze znajomymi. Na miejscu cudzoziemca i tych ludzi, którzy tutaj przyjeżdżają, to jest tragedia. To chyba nie jest miejsce przyjemne, żeby się spotkać z kimś.

W przypadku zmiany przepisów można by umożliwić cudzoziemcom wyrażającym takie potrzeby wykonywanie jakichś drobnych prac ogrodowych i in., a także otwarcie dla nich sklepiku w ośrodku.

\section{Jaki ośrodek (lokalizacja, architektura, profil działalności)?}

Lokalizacja ośrodków detencyjnych w miastach jest dobrym, praktycznym rozwiązaniem ${ }^{6}$. Nie ma znaczenia typ zabudowy, istotne jest tylko to, aby wszystkie zespoły i sekcje znajdowały się w jednym budynku. Reprezentatywne wypowiedzi:

To zależy, co bierzemy pod uwagę, czy własną wygodę, czyli bieganie po schodach, to lepiej parterowy, tak, natomiast, jeżeli chodzi o rozdzielenie nacji, narodowości, to lepiej jest piętrowy, bo wtedy jest możliwość (...)

$6 \quad$ Tylko jeden ośrodek (Lesznowola) jest usytuowany w kompleksie leśnym. Za lokalizacją miejską przemawiają względy praktyczne: bliskość placówek medycznych, do których często dowożeni są cudzoziemcy, oraz dojazdy funkcjonariuszy do pracy. 
Albo skrzydła parterowe, w kształcie plusa tak jakby. Najwygodniej by było, gdybyśmy wszyscy byli w jednym budynku. Administracja i inne.

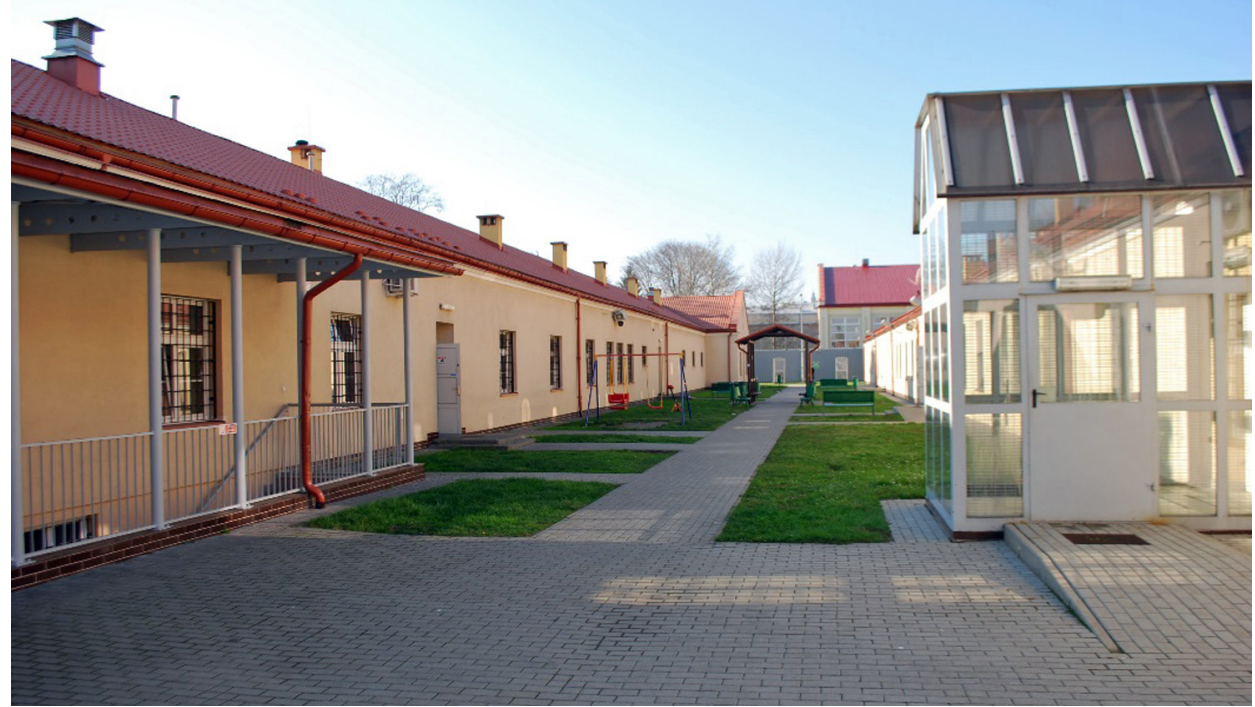

Fot. 4. Różnorodność rozwiązań architektonicznych (Przemyśl), listopad 2018 (fot. D. Niedźwiedzki)

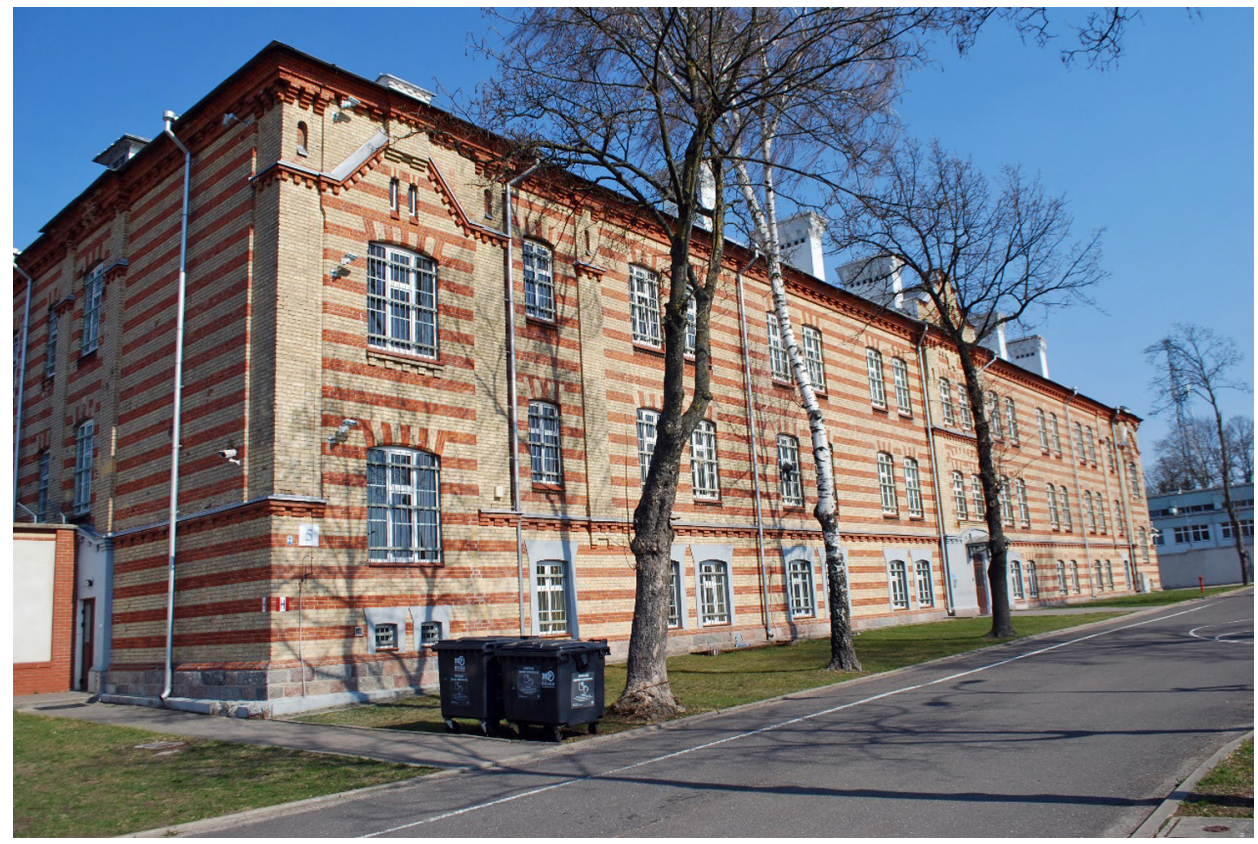

Fot. 5. Różnorodność rozwiązań architektonicznych (Białystok), maj 2019 (fot. J. Schmidt) 


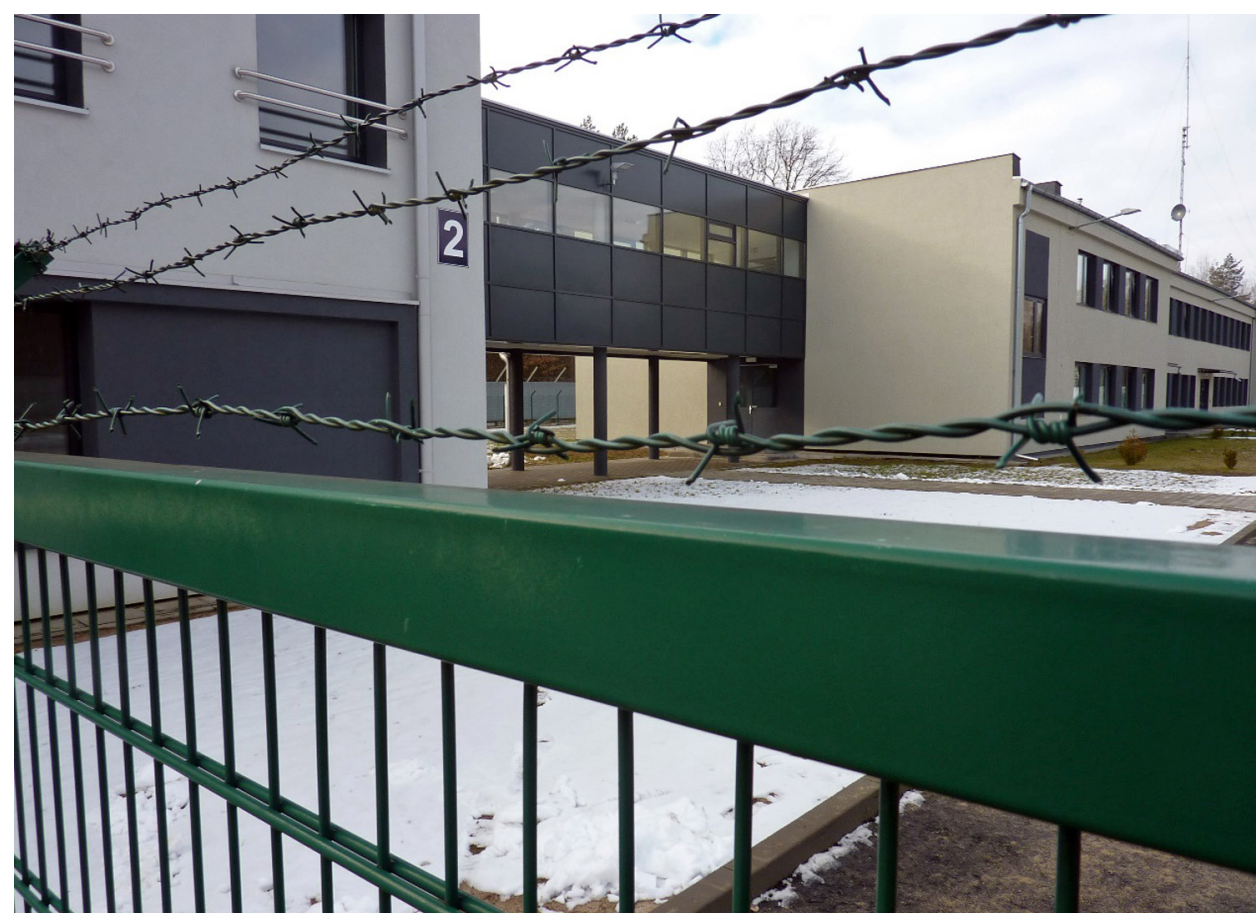

Fot. 6. Różnorodność rozwiązań architektonicznych (Lesznowola), luty 2019 (fot. D. Niedźwiedzki)

Obecne ośrodki są przewidziane dla zbyt dużej liczby cudzoziemców, co negatywnie wpływa na sprawy bezpieczeństwa, efektywność zarządzania i panującą tam atmosferę. Reprezentatywne wypowiedzi:

Pułap tak maksymalnie do siedemdziesięciu miejsc (...) Jest to łatwiejsze do ogarnięcia jednak. U nas jest ponad s etka, tak że to jest już za dużo (...) Bo w tej chwili ja nie jestem w stanie zrobić nic w ośrodku. Bo jest pełen cudzoziemców, jest harmider, cały czas coś chcą ode mnie. Bo ja tam jestem. Nawet jak dzwonię do kogoś z was, to mimo wszystko jakby (...) to nie jest w tej chwili, to nie to, że przychodzi i ci głowę zawraca, a cały czas mając cudzoziemca przy sobie, to praca taka jakaś (...) skupić się, napisać notatkę czy też drugi dzień piszę raport z sytuacji nadzwyczajnej i nie mogę.

Wszystkie ośrodki detencyjne powinny mieć profil mieszany - przyjmować zarówno mężczyzn, jak i kobiety, osobne jednostki winny stanowić ośrodki rodzinne. Reprezentatywne wypowiedzi:

Nie powinny być ośrodki tylko o profilu np. męskim. Nie powinno być takiego rozgraniczenia (...) żeby ci cudzoziemcy czuli swobodę, dokładnie. Tak samo uważam, że tak, jak wcześniej był tutaj profil męski i żeński, to też 
pozytywnie wpływało. Ale nie, to naprawdę (...) Ja bym chciał, żeby to wróciło. Bo było widać, że to zachowanie cudzoziemców jest całkiem inne po prostu. Inne relacje, mniejsza frustracja tych cudzoziemców. Tak to siedzieli sobie na tych spacerniakach, rozmawiali, całkiem inaczej to wyglądało. Raz, że te kobiety też tam dbały bardziej o porządek (...) To ciasto upiekły, to zniosły na spacerniak, to naprawdę łagodziło te emocje... I ci cudzoziemcy byli jacyś tam weseli bardziej, bo się uśmiechali, wiadomo (...) Dbali o siebie bardziej. Myli się więcej.

\section{Organizacja pracy}

Należałoby usprawnić obieg informacji. Po pierwsze ustalenia podejmowane podczas odpraw kierowniczych winny być niezwłocznie przekazywane funkcjonariuszom, aby każdy z nich mógł zaznajomić się z aktualnym profilem działań, wiedział, co ma robić, na co zwracać szczególną uwagę. Po drugie, należałoby zintensyfikować partnerską współpracę między osobami pracującymi w różnych zespołach/sekcjach, tworzyć bieżące banki informacji o cudzoziemcach. Reprezentatywne wypowiedzi:

My czerpiemy informacje z sekcji ochrony, przekazujemy sekcji ochrony, co przekazali w sensie decyzji, negatywna, zachowanie, jak się rozstaliśmy, w jakim nastroju, żeby zwrócić uwagę, że był nerwowy, że coś może się wydarzyć, że jest niezadowolony z jakiegoś tam rozstrzygnięcia. Też przekazujemy to sekcji edukacyjnej, bo za chwilę wiem, że przychodzi, wypłakuje się i tu już osoby z sekcji wiedzą, co on otrzymał. Tutaj czujemy się tak sami między sobą bezpiecznie. Ale nie zawsze tak jest - często sekcje przerzucają się obowiązkami (...)

Kolejną niezwykle istotną sprawą do rozwiązania jest przypisywanie funkcjonariuszowi do obowiązków etatowych zbyt wielu zadań, w tym wykraczających poza jego kompetencje. A już w ogóle niedopuszczalną praktyką powinno być przenoszenie funkcjonariusza $z$ jednego zespołu do innego, co wymaga uczenia się całkowicie nowych, często zupełnie nieznanych czynności:

Jeśli ktoś jest specjalistą, to niech będzie specjalistą w jednym kierunku. Mamy zawyżone zakresy etatu po prostu. Powinien panować tu przejrzysty podział zadań. 


\section{Relacje między funkcjonariuszami a cudzoziemcami}

Pierwszy dezyderat dotyczył potrzeby większego dyscyplinowania cudzoziemców zgodnie z obowiązującymi regulaminami. Takie dyscyplinowanie ma dotyczyć przestrzegania regulaminu dnia, poszanowania dla mienia, utrzymywania porządku w pomieszczeniach sypialnych oraz regulacji odnoszących się do miejsca i czasu przyjmowania cudzoziemca przez funkcjonariusza. Reprezentatywne wypowiedzi:

Szósta rano pobudka - wszyscy wstają! Cisza nocna i nie ma wychodzenia z pokojów! Tak mi się teraz właśnie nasunęło a propos tutaj mówimy zasada, zasada. Myślę, że powinien być, mimo wszystko, plan dnia. Czyli coś takiego jak określony plan dnia. Żeby oni też mieli takie poczucie funkcjonowania.

Jeżeli no może nie zdecydowana większość, ale wielu z tych cudzoziemców nie szanuje tego sprzętu, który mają do użytkowania i który jest komfortowy, w takim wypadku zapewnianie im komfortu jeszcze większego jeszcze bardziej gdzieś tam moim zdaniem te zachowania pogłębia. Że oni (...) no dobrze, dostaną do pokoju nowe łóżko. I oni wychodzą z tego założenia, że to nie jest ich majątek, to nie jest ich, oni tylko tymczasowo przebywają w tym miejscu, więc po co o to dbać. To trzeba by odpowiednią osobę wyznaczyć, która egzekwowałaby, jeżeli cudzoziemiec zniszczy dany mebel czy rzecz w pokoju, to my możemy wszcząć postępowanie szkodowe. U nas w ośrodku takich postępowań się nie wszczyna. Nie ma osób, które się tym zajmą. Natomiast Przemyśl świetnie sobie z tym radzi. Oni w momencie, kiedy cudzoziemca (...) jest od razu informowany o tym, że uszkodził (...) pieniądze są ściągane, on za to płaci. On o tym wie, że jak zniszczy, to będzie płacił. A u nas jest bezkarność. Zniszczy, a nikt nawet nie przyjdzie i mu palcem nie pogrozi. Jest sporządzona jakaś notatka, bo stwierdzono, że jest uszkodzone. I tyle. A później (...)

No tak, dbanie o pomieszczenia mieszkalne, gdzie niejednokrotnie wchodzi się do pomieszczenia, to aż odrzuca. Wynoszenie śmieci (...)

Drugi dezyderat wiązał się $z$ typem relacji, jakie funkcjonariusz powinien budować $\mathrm{z}$ osobą umieszczoną $\mathrm{w}$ ośrodku. Wszyscy uczestnicy badań byli zgodni, że modelowe zachowanie powinno polegać na utrzymaniu pewnego dystansu, wystrzeganiu się budowania więzi o charakterze zażyłości. Reprezentatywne wypowiedzi:

Chyba na dystans, bo jeśli człowiek chce naprawdę pokazać, wytłumaczyć, powiedzieć, to zaczynają może nie wykorzystywać, ale być z pretensjami. Jeśli człowiek z sercem podchodzi, to potem zaczyna wyzywać i nie ma szacunku. Kawa z cudzoziemcem czy rozmowa na stojąco? Ja myślę, że na stojąco, bo u nas wszędzie w każdym kraju, policjant, jeśli chce pouczyć, 
to nie siada i nie pije kawy. My też działamy na przepisach prawa. Oni nie przychodzą do nas i nie są umieszczani w nagrodę. Jest jakieś przewinienie, przyczyna. Są grupy typu dydaktyczna, które prowadzą jakieś tam zajęcia, jest integracja. Moim zdaniem funkcjonariusz ochrony nie może sobie pozwolić na to, żeby ktoś mu wchodził na głowę. Jeżeli osadzony będzie czuł, że wszyscy podchodzą na miękkich nogach do niego, nie będzie szacunku.

Priorytetem $\mathrm{w}$ relacjach z cudzoziemcami powinien być wzajemny szacunek połączony ze stanowczością. Reprezentatywne wypowiedzi:

Trzeba ich szanować. Nie traktować ich z góry. Normalnie do nich podchodzić. Jeżeli oni widzą, że się ich nie lekceważy - masz pismo, podpisz się i cześć. I im się nie wytłumaczy, to też oni inaczej do tego podchodzą. $\mathrm{Z}$ dużym dystansem i często są nieufni i nie podpisują. Trzeba wytłumaczyć im, czego pismo dotyczy i jakie są postępowania. Wiadomo, trzeba być człowiekiem stanowczym, konsekwentnym, a jednocześnie empatycznym, nie spoufalać się, podchodzić z dystansem do cudzoziemców i należy myśleć w kontaktach z cudzoziemcami. Używać rozumu. Ale to trwa latami, to nabieranie doświadczenia w kontaktach z cudzoziemcami. Trzeba kilka lat, żeby naprawdę się wdrożyć i sprawnie się z nimi komunikować; chciałabym, żeby tak, jak my się do nich zwracamy, mi się wydaje, ja od swojej strony tak robię, zwracamy się do nich z szacunkiem, to też byśmy chcieli, żeby ten szacunek i od nich egzekwować. Czyli jeżeli ja zwracam się do nich z szacunkiem, to chciałabym, żeby oni zwracali się z szacunkiem. Jeżeli się nie zwracają z szacunkiem, to chciałabym, żeby to było egzekwowane.

Nie można przy tym zapominać o kwestiach bezpieczeństwa, które może być zagrożone wskutek nieodpowiedniego zachowania lub przekazania niewłaściwych informacji. Szczególnie ważne jest przewidywanie i unikanie sytuacji konfliktowych, które mogą pojawiać się w różnych codziennych sytuacjach, a także sytuacjach szczególnych, takich jak np. wręczanie cudzoziemcowi decyzji sądowej w jego sprawie. Zapobieganie konfliktom musi wiązać się z zagospodarowywaniem czasu cudzoziemcom. Reprezentatywne wypowiedzi:

Bezpieczeństwo osobiste. Kultura rozmowy, informacje na różnych płaszczyznach, czyli funkcjonariusz-cudzoziemcy, funkcjonariusz-funkcjonariusz, tutaj wymiana informacji pomiędzy nami, jako osobami z różnych sekcji. I przede wszystkim przełożony-funkcjonariusz, żeby wszędzie był przekaz tej informacji. Znajomość przepisów, regulaminów, żeby starać się jednak zachować spokój, opanowanie, równowagę, traktować cudzoziemca jak człowieka. Nie dyskryminować go ze względu na tę rasę, kulturę, odmienność. Traktować go jak człowieka. I jeszcze ważna rzecz - nie sprzedawać dla cudzoziemców informacji na temat osób pracujących w strzeżonych ośrodku, na temat funkcjonariuszy, ich danych osobistych. To jest naprawdę 
bardzo ważne. To jest ze względu na nasze bezpieczeństwo. Różni ludzie są tu umieszczani, naprawdę różne przypadki.

Chodzi o te nasze spotkania z cudzoziemcami, w sensie (...) spotkania w celu udzielenia im informacji. Mamy w tej chwili coś takiego. Zależy, jacy są cudzoziemcy, bo jak jeden powie, że ja mam narzucone z góry, spotkania są w środę od trzynastej, a on w tym czasie jest zmęczony, to on do mnie nie przyjdzie, ale jutro przyjdzie z pretensją, że dlaczego ja mu nie powiedziałam, bo przecież ja mogłam mu przyjść do pokoju to powiedzieć. Więc my wychodzimy z inicjatywą, jesteśmy elastyczni i tak jak moja sekcja, zresztą myślę, że wszystkie sekcje na tej zasadzie działają, żeby uniknąć konfliktowych sytuacji, to ja po prostu czasami odstawiam swoją dumę i wiem: Nie wchodzić w butach do sali modlitw, szczególnie podczas obecności modlących się. Mówimy o sali modlitw muzułmanów. Drugie - nie spoufalać się z cudzoziemcami. Trzecie - mieć ciągłą świadomość pozornego spokoju, bo w każdej chwili może dojść do zbiorowej bójki. Czwarte - nie składać cudzoziemcom obietnic. I wystarczy.

(...) że jeżeli ja tego w tej chwili nie zrobię, tak, no to ja wiem, że on (...) Ale to też nie jest na zasadzie, że muszę przyjść, tylko dobrze, zrobię swoją czynność, przychodzę po godzinie, ale przychodzę.

Ja bym chciała dodać jeszcze do tego, co wszyscy mówią, to jeszcze taką możliwość zagospodarowania im czasu, bo mam takie wrażenie, że wchodząc na oddział, ja widzę takie ich znużenie, zmęczenie, takie... apatyczni tacy są. Ale żeby im dać tą możliwość, to muszą być osoby, które będą chciały zaangażować się. Musza być środki na to. I czasem jest tak, że dziś ich nie widać, a potem sami przyjdą. Konflikt pojawia się wtedy, kiedy cudzoziemiec ma dużo czasu do myślenia i (...) gdyby miał więcej dodatkowych zajęć, np. organizowanych przez nas, gdybyśmy organizowali, to oni by mieli mniej czasu, żeby wchodzić w te konflikty, bo cały czas, codziennie, mieliby dostęp do jakichś tam rozrywek czy (...) czas by szybciej im zlatywał tutaj i nie byłoby takich sytuacji. Nie przewidzi się tych reakcji cudzoziemca, bo przez pięć miesięcy pracy jako opiekun powrotowy on może być OK, bardzo dobrze nam się współpraca może układać, natomiast przychodzi taki dzień, kiedy ja doręczam mu decyzję, bądź informację przekazuję, która nie jest dla niego korzystna i on wtedy wybucha. I ja nie wiem, co on może mi zrobić. On może rzucić się do szyi, tak.

\section{Relacje między cudzoziemcami}

W celu uniknięcia konfliktów niezwykle pożądane jest rozlokowanie cudzoziemców w pokojach według klucza wyznaniowego, etnicznego, czasami także 


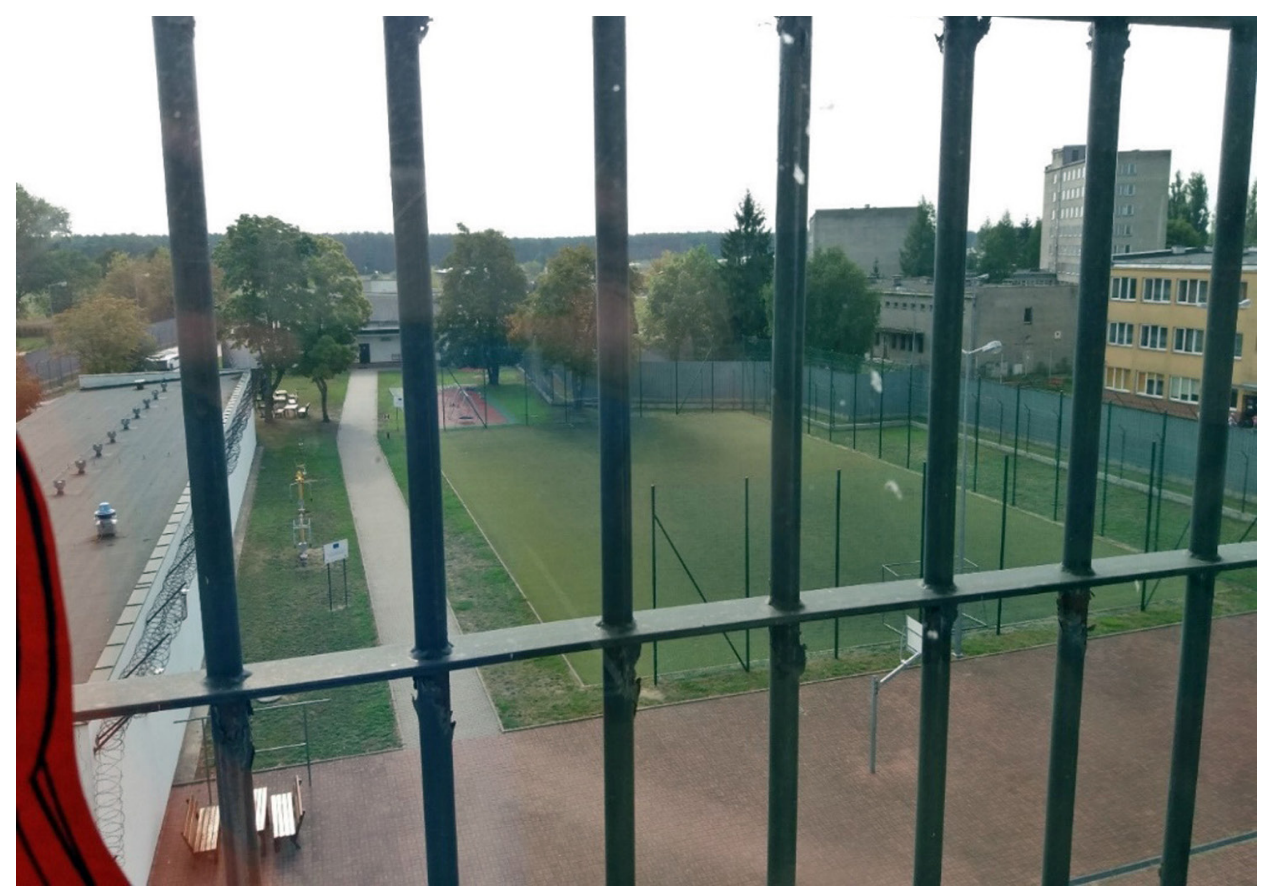

Fot. 7. Przestrzeń rekreacyjna (Biała Podlaska), wrzesień 2018 (fot. D. Niedźwiedzki)

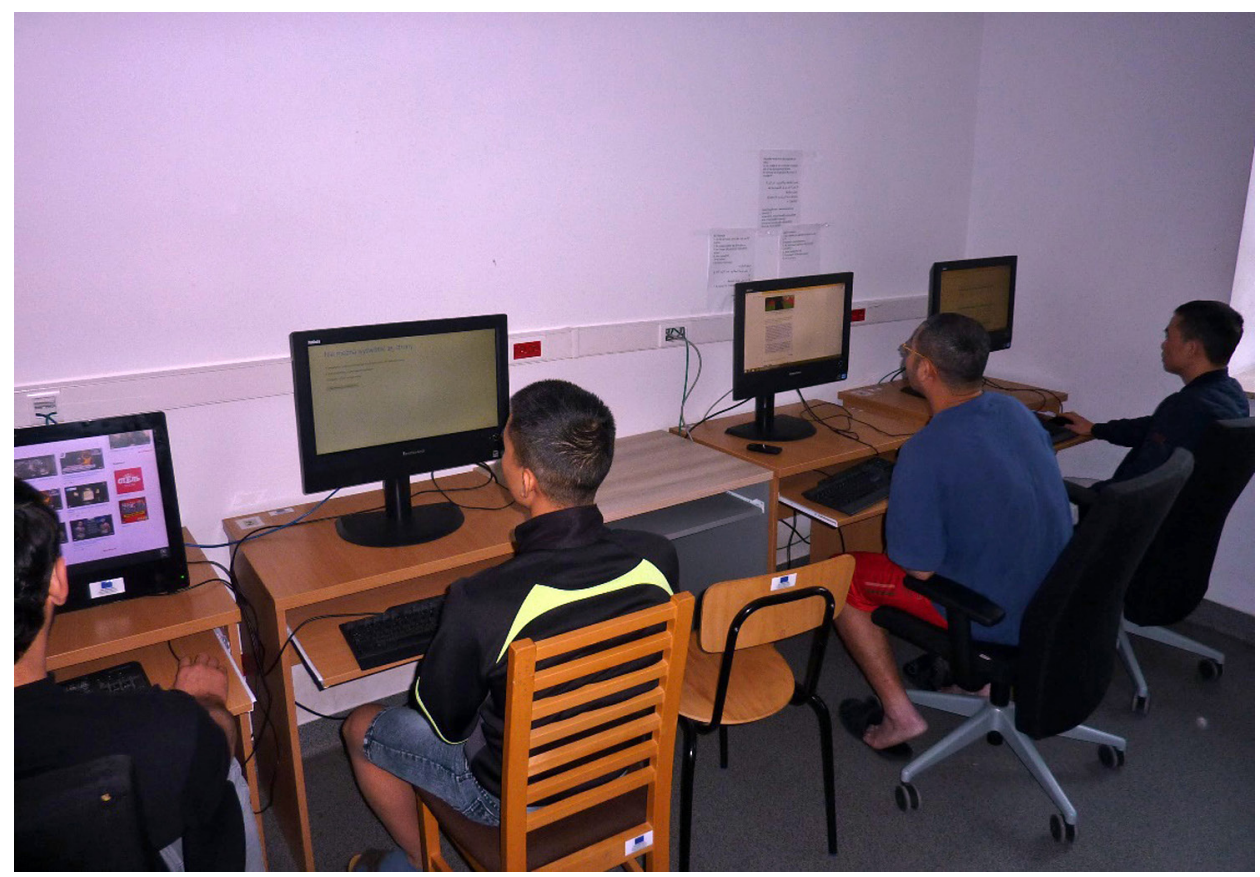

Fot. 8. Sala komputerowa (Lesznowola), luty 2019 (fot. J. Schmidt) 
rasowego. W szczególności dotyczy to muzułmanów i imigrantów pochodzących z Czeczenii i innych części Kaukazu. Ta kwestia jest ściśle powiązana z relacjami płci, które wymagają wprowadzenia pewnych podziałów przestrzeni (np. oddzielnych świetlic). Reprezentatywne wypowiedzi:

Odseparowania ze względów wyznaniowych, żeby podział był. To są grupy, które nie akceptują pewnych kobiet, zwłaszcza muzułmanek, grupy, które nie akceptują innych pod katem wyznaniowym. No i do tego dochodzi z tego tytułu do konfliktów, sporów. Bo tutaj warto by było pomyśleć, żeby te dwie części mieszkalne jakoś oddzielone były, żeby ograniczyć ich kontakt. Nawet pod kątem ubioru (...) Zaraz, bo ktoś wyzywająco jest ubrany, bo nie jest muzułmaninem, albo w ogóle jest $z$ innej grupy etnicznej, religijnej, już powód do sporu. Często kobiety siedzą, telewizor gra, przychodzą mężczyźni, one muszą opuścić już (...) Najważniejsza jest jednak ta religia. Bo ta religia jest (...) Biały - czarny, ale jest tego samego wyznania i bez problemu się dogadają. Ale będzie muzułmanin - chrześcijanin to tylko iskierka (...) i (...) i może być niezła zadyma $z$ tego. Tylko czasami jest to zabawne, bo czarny muzułmanin jest $\mathrm{w}$ porządku, ale czarny chrześcijanin już nie, bo to też czasami było widoczne. Dlatego sami powinni się bardziej określić, na co reagują. Nawet między Czeczenami są różnice. Ja to widzę z racji doświadczenia zawodowego, pracowałam w sądownictwie i szybko rzucają mi się w oczy ludzie funkcjonujący na marginesie tamtego społeczeństwa i naszego społeczeństwa. My mamy do czynienia w ośrodku, szczególnie w ostatnich latach, bardzo dużo osób, które przyjeżdżają, to nie są uchodźcy polityczni, to jest margines społeczny, który chciałby dobrze żyć i to jest bardzo zauważalne. Bardzo zauważalne. To jest ta duża roszczeniowość tych cudzoziemców właśnie. Z wszystkiego są niezadowoleni, tego nie akceptują, a jak coś się da, zaproponuje, nie akceptują. Taniec? Jaki taniec, oni nie dotykają osobników płci przeciwnej. Była organizowana pierwsza pomoc w nagłych przypadkach, no to też nie mogą dotknąć mężczyzny, tak się zachowywały niektóre Czeczenki.

\section{Zakończenie}

W powyższej wstępnej ${ }^{7}$ prezentacji projekcji funkcjonariuszy ujawniły się interesujące wizje optymalizacji funkcjonowania ośrodków detencyjnych, które, można tak zakładać na podstawie badań indywidualnych, znaczaco różnią się od optyki modernizacji przedmiotowej instytucji, która przedkładaja funkcjonariusze reprezentujący wyższy i średni szczebel kierownictwa ośrodków oraz decydenci we władzach centralnych SG. Dobrym

7 Przedłożona w tekście analiza miała jedynie formę interpretacji formułującej ukierunkowanej na uporządkowanie tematów wiodących i cząstkowych. W kolejnym etapie prac nad tym materiałem będzie przeprowadzona interpretacja refleksywna koncentrująca się nad tym, jak badani wyrażali swoje przekonania i ukierunkowali dyskusję (Krzychała 2004, s. 58-63). 
świadectwem takiego stanu rzeczy jest rozpoczęcie prac nad budowa kolejnego, wielkiego ośrodka detencyjnego $w$ Lesznowoli, który ma pomieścić ponad pót tysiaca cudzoziemców. Sami cudzoziemcy oraz obrońcy praw człowieka nie prezentuja żadnej wizji idealnego ośrodka detencyjnego, gdyż w ogóle negują zasadność istnienia takiej instytucji. W chwili obecnej na terenie 46 państw (Unia Europejska i państwa ościenne) działa blisko pięćset ośrodków detencyjnych, $w$ których każdego roku umieszczanych jest ponad 500 tys. cudzoziemców (Niedźwiedzki, Schmidt 2020, s. 18).

\title{
Literatura
}

Augé M. 2010. Nie-miejsca. Wprowadzenie do antropologii hipernowoczesności. Przeł. R. Chymkowski. PWN, Warszawa.

Barbour R. 2011. Badania fokusowe. Przeł. B. Komorowska. PWN, Warszawa.

Bentham J. 1835. The Works of Jeremy Bentham. Vol. 4. John Browning (https://oll.libertyfund.org/ titles/bentham-the-works-of-jeremy-bentham-vol-4).

Bohnsack R. 2004. Dyskusja grupowa - teoria i praktyka rekonstrukcji kolektywnych wzorów orientacji. [W:] S. Krzychała (red.), Społeczne przestrzenie doświadczenia. Metoda interpretacji dokumentarnej. Wydawnictwo Naukowe Dolnośląskiej Szkoły Wyższej Edukacji TWP, Wrocław, s. 36-48.

Bosworth M. 2014. Inside Migration Detention. Oxford University Press, Oxford.

Foucault M. 1983. Nadzorować i karać. Narodziny więzienia. Przeł. T. Komendant. Wydawnictwo Fundacji Aletheia, Warszawa.

Foucault M. 2005. Inne przestrzenie. Przeł. A. Rejniak-Majewska. Teksty Drugie, 6: 117-125.

Krzychała S. 2004. Dokumentarna interpretacja tekstu - od samobieżnego toku dyskusji do refleksywnej interpretacji dyskursu. [W:] S. Krzychała (red.), Społeczne przestrzenie doświadczenia. Metoda interpretacji dokumentarnej. Wydawnictwo Naukowe Dolnośląskiej Szkoły Wyższej Edukacji TWP, Wrocław, s. 49-63.

Labanca N., Ceccorulli M. 2014. Introduction. [W:] M. Ceccorulli, N. Labanca (red.), The EU. Migration and the Politics of Administrative Detention. Routledge, London-New York, s. 1-16.

Niedźwiedzki D., Schmidt J. 2020. Detencja cudzoziemców w Polsce. Perspektywa teoretyczno-metodologiczna. Nomos, Kraków.

Sieniow T. 2016. Stosowanie alternatyw do detencji cudzoziemców w Polsce w latach 2015-2015. Raport z monitoringu. Instytut na rzecz Państwa Prawa, Lublin.

Tokarczuk O. 2007. Bieguni. Wydawnictwo Literackie, Kraków.

Ustawa z dnia 12 grudnia 2013 r. o cudzoziemcach (Dz.U. z 2013 r., poz. 1650, t.j. Dz.U. z 2020 r., poz. 35).

\section{"The perfect space": the perspective of the management of guarded detention centers for foreigners in Poland}

\begin{abstract}
The space in detention centers for foreigners in Poland is guarded by the border guards and it is unavailable for outsiders. Therefore, there is no opportunity for researchers to observe the practices related to administering this space and regulating the behavior of the staff and the detainees. Between 2018 and 2019, a first exploratory study in Poland targeted at the identification of rules and standards of the material organisation of the centers' space and the performance of all the categories social actors. This article presents some results of the study regarding the centers' management's image of how the perfect detention center should be designed and organised. For data collection, the study used focus group interviews (FGI) in all Polish guarded detention centers.
\end{abstract}

Key words: guarded centres for foreigners, detention, space/non-place 